\title{
Improvement of Spectrophotometric Method for the Determination of Atrazine in Contaminated Water by Inducing of Mannich Reaction
}

\author{
Karine Assaker ${ }^{1,2} \&$ Jamil Rima ${ }^{1}$ \\ ${ }^{1}$ Department of Chemistry, Physical Chemistry Environmental Engineering and Biology, Lebanese University \\ Faculty of Sciences II, Lebanon \\ ${ }^{2}$ Equipe Physico-chimie des colloïdes, Laboratoire SRSMC, Université de Lorraine, Nancy, France \\ Correspondence: Jamil Rima, Department of Chemistry, Physical Chemistry Environmental Engineering and \\ Biology, Lebanese University Faculty of Sciences II, Lebanon. E-mail: jamil.rima1@gmail.com
}

Received: June 27, 2012 Accepted: August 2, 2012 Online Published: September 5, 2012

doi:10.5539/jfr.v1n4p17 URL: http://dx.doi.org/10.5539/jfr.v1n4p17

\begin{abstract}
The objective of this study is to develop a simple and economic spectrophotometric method for the quantitative determination of atrazine. This method is based on the complexation of atrazine derivatization (dechlorinated atrazine [DA]) with a mixture of formaldehyde and ketone compound, as described by Mannich reaction. The complex was determined by UV-Vis absorption measurement and the ketone compound used was the uranine due to its high coefficient absorption. The UV spectrum of the complex shows maxima of absorption at $207 \mathrm{~nm}$ and at $227 \mathrm{~nm}$. An internal standard was used to quantify the atrazine. There is a good linearity between the absorbance and the concentration in the range of $0.1-10 \mu \mathrm{g} \cdot \mathrm{mL}^{-1}$ of atrazine. The recovery value was $97 \%$ and the limit of detection was $0.01 \mu \mathrm{g} \cdot \mathrm{mL}^{-1}$. Real samples collected from irrigation local area were analyzed using this method and the estimated concentration of atrazine found in the mentioned river is $0.29 \pm 0.011 \mu \mathrm{g} \cdot \mathrm{mL}^{-1}$.
\end{abstract}

Keywords: atrazine, dechlorination by zero valent iron, Mannich reaction, spectrophotometer, quantification, internal standard, real samples measurements

\section{Introduction}

Atrazine is widely used in agriculture, and their heavy uses have resulted in environmental pollution. Their persistent presence had been a serious problem, especially in surface and ground water systems (Gianessi \& Marcelli, 2000). Atrazine herbicides were often used especially in Europe and the United States (Gianessi \& Marcelli, 2000; Gammon et al., 2005), since they have been greatly used in maize cultivation and forestry. Their solubility in soil is low, and it can migrate along the food chain. Their intense use and presence in the environment have created a health threat to human beings. Recently, they have been considered to be endocrine disrupting chemicals (Jiang et al., 2006). Water Directive (EEC 80/778) on the maximum admissible concentrations in drinking water as $0.1 \mathrm{mg} . \mathrm{L}^{-1}$ for an individual herbicide and $0.5 \mathrm{mg} \mathrm{L}^{-1}$ for total pesticides (EEC Drinking Water Guidelines, 1980a) whereas in surface water the alert and alarm threshold values are typically 1 and $3 \mathrm{mg} . \mathrm{L}^{-1}$ (EEC Drinking Water Guidelines, 1980b). Hence, the developments of sensitive and economic analytical methods are very crucial for screening the quantitative presence of atrazine and preventing toxicological risks. In general, gas chromatography (GC) and high performance liquid chromatography (HPLC) are the techniques popularly used for the determination of atrazine and simazine (Usenko et al, 2005; Stalikas, Knopp \& Niessner, 2002; Koal et al., 2003; Baranowska, Barchanska, \& Pacak, 2006). Gas chromatography-mass spectrometry (GC-MS), amperometric immunosensor, and adsorptive stripping voltammetric determination were developed for the analysis of atrazine and simazine (Maleki et al., 2007; Grennan et al., 2003; Turiel et al., 1998; Nevado et al., 2007).

In general, these techniques are expensive and involve time-consuming separation steps. These methods are unsuitable for field-testing, for continuous monitoring or for screening high numbers of samples as required in mapping pesticide pollution in time and space.

The objective of this work is to analyse atrazine by an economic and rapid method. The proposed method in this work is based on the dechlorination of atrazine [DA] by zero valent iron powder (ZVIP), according to Ghauch et al. (1999). The [DA] was used in Mannich reaction in order to obtain a byproduct having a higher 
extinction coefficient than atrazine.

\section{Materials and Methods}

\subsection{Chemicals and Reagents}

All chemicals and solvents used were of analytical grade or of a higher grade when available. Formaldehyde and hydrochloric acid were purchased from Fisher (MA, USA). Atrazine was purchased from Rodel-dehein, zero valent iron powder (350 mesh) was purchased from Sigma Aldrich Ultra pure water was prepared using a multi-Q filter system (Millipore, MA, USA).

\subsection{Instruments}

The UV absorption measurements were performed on a Shimadzu UV- 1650 PC. With $10 \mathrm{~mm}$ quartz cells were used for spectrophotometric measurements. The $\mathrm{pH}$ values are measured using METTLER TOLEDO $\mathrm{pH}-\mathrm{meter}$.

\subsection{Standard Solutions}

Stock solution of atrazine was prepared in a volumetric flask at a concentration of $10 \mu \mathrm{g} \cdot \mathrm{mL}^{-1}, 10 \mathrm{~mL}$ of this solution were mixed with $20 \mathrm{~mL}$ of acidified di-ionized water $(\mathrm{pH}=4)$ and transferred into a flask of $100 \mathrm{~mL}$. $2.5 \mathrm{~g}$ of zero valent iron powder were also added into the flask and shacken for 15 minutes.

According to our previous work (Ghauch et al., 1999), we have demonstrated that after 15 minutes the atrazine at this concentration is completely dechlorinated. This solution was then used in Mannich reaction.

\subsection{Calibration Curves}

Samples for analysis were prepared by mixing uranine, formaldehyde and dechlorinated atrazine solutions. De-ionized water was transferred into each sample to reach a final volume of $10 \mathrm{~mL}$. Calibration curves were built for quantitative measurements using the samples prepared according Table 1.

Table 1. Data for regression curve (Absorbance of Mannich complex $=f[D A]$ )

\begin{tabular}{llllll}
\hline $\begin{array}{l}\text { Number } \\
\text { of } \\
\text { solution }\end{array}$ & $\begin{array}{l}\text { Volume of dechlorinated } \\
\text { atrazine } \\
(\mathrm{mL})[\mathrm{DA}]=1.5 \mu \mathrm{g} \cdot \mathrm{ml}^{-1}\end{array}$ & $\begin{array}{l}\text { Volume } \\
\text { uranine } \\
\text { solution } \\
\mu \mathrm{g} / \mathrm{mL})\end{array}$ & $\begin{array}{l}\text { of } \\
(10\end{array}$ & $\begin{array}{l}\text { Volume } \\
\text { formaldehyde } \\
(\mathrm{mL})\end{array}$ & $\begin{array}{l}\text { of } \\
\text { wolume of acidified } \\
(\mathrm{mL})\end{array}$ \\
\hline I & 1 & 0 & 1 & 8 \\
II & 2 & 0.5 & 1 & 6.5 \\
III & 3 & 0.5 & 1 & 5.5 \\
IV & 4 & 0.5 & 1 & 4.5 \\
V & 5 & 0.5 & 1 & 3.5 \\
VI & 6 & 0.5 & 1 & 2.5
\end{tabular}

Note: Composition of samples used to build regression curve of the absorbance of the complex obtained by Mannich reaction and atrazine dechlorinated [DA].

\subsection{Internal Standard Curve Addition and Recovery}

Dechlorinated atrazine was added as an internal standard for the calibration of the measurement (Muel \& Lacroix, 1960; Rima, Lamotte, \& Joussot-Dubien, 1982). Determination of the $\mathrm{pH}$ was done using a Mettler Toledo (OH, USA) pH-meter.

Samples for analysis were prepared by mixing $0.5 \mathrm{ml}$ of uranine $\left(10 \mu \mathrm{g} \cdot \mathrm{mL}^{-1}\right), 1 \mathrm{~mL}$ of pure formaldehyde and different volumes of dechlorinated atrazine stock solutions diluted to $\left[0.75 \mu \mathrm{g} \cdot \mathrm{mL}^{-1}\right](1-1.5-2-2.5$ and $3 \mathrm{~mL})$. De-ionized water was transferred to each sample to reach a final volume of $5 \mathrm{~mL}$. Table 2 describes the preparation of the standard curve. 
Table 2. Data for internal standard addition curve

\begin{tabular}{|c|c|c|c|c|}
\hline $\begin{array}{l}\text { Number of } \\
\text { solution }\end{array}$ & $\begin{array}{lr}\text { Volume } & \text { of } \\
\text { dechlorinated } & \\
\text { atrazine } & {[0.75} \\
{\left[\mu \mathrm{g} \cdot \mathrm{mL}^{-1}\right]} & \text { solution } \\
(\mathrm{mL}) & \end{array}$ & 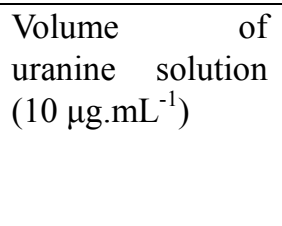 & $\begin{array}{l}\text { Volume of } \\
\text { formaldehyde } \\
(\mathrm{mL})\end{array}$ & $\begin{array}{l}\text { Volume of acidified } \\
\text { water }(\mathrm{pH}=4) \text { added } \\
(\mathrm{mL})\end{array}$ \\
\hline I & 1 & 0 & 1 & 3 \\
\hline II & 1 & 0.5 & 1 & 2.5 \\
\hline III & 1.5 & 0.5 & 1 & 2 \\
\hline IV & 2 & 0.5 & 1 & 1.5 \\
\hline V & 2.5 & 0.5 & 1 & 1 \\
\hline VI & 3 & 0.5 & 1 & 0.5 \\
\hline
\end{tabular}

Note: Composition of the samples used to build the internal standard curve.

Recovery experiments were performed by standard addition method: $0.15 \mu \mathrm{g} \cdot \mathrm{mL}^{-1}$ of Atrazine dechlorinated was added to samples and percentage of recovery ( $\mathrm{R} \%)$ was calculated as follows:

$\mathrm{R} \%=[(\mathrm{Cr}-\mathrm{Cf}) / \mathrm{Cr}] \times 100$

$\mathrm{Cr}=$ Real concentration of atrazine in the fortified samples

$\mathrm{Cf}=$ Concentration of atrazine obtained by the internal standard addition curve

\subsection{River Water Analysis}

The analyzed water was collected from river north of Lebanon, which is an agricultural area. $100 \mathrm{~mL}$ of the polluted water were treated by zero valent iron powder according to the protocol mentioned above. The samples were fortified by solutions of dechlorinated atrazine having an initial concentration of $0.75 \mu \mathrm{g} \cdot \mathrm{mL}^{-1}$ in order to build the internal standard curve. Table 3 summarizes the volumes of different solutions used in the mixtures.

Table 3. Data to use internal standard addition method in the atrazine determination in the real samples

\begin{tabular}{llllll}
\hline $\begin{array}{l}\text { Volume of river } \\
\text { water after treatment } \\
\text { by } \mathrm{Fe}^{0}(\mathrm{~mL})\end{array}$ & $\begin{array}{l}\text { Volume } \\
\text { dechlorinated atrazine } \\
{\left[0.75 \mu \mathrm{g} \cdot \mathrm{ml}^{-1}\right](\mathrm{mL})}\end{array}$ & $\begin{array}{l}\text { Volume } \\
\text { uranine } \\
\text { solution } \\
\left.\mu \mathrm{g} \cdot \mathrm{ml}^{-1}\right)\end{array}$ & $\begin{array}{l}\text { of } \\
(10\end{array}$ & $\begin{array}{l}\text { Volume } \\
\text { formaldehyde } \\
(\mathrm{mL})\end{array}$ & $\begin{array}{l}\text { of } \\
\begin{array}{l}\text { Volume } \\
(\mathrm{mL})\end{array}\end{array}$ \\
\hline 0 & 1 & 0.5 & 1 & 2.5 \\
0.5 & 1 & 0.5 & 1 & 2 \\
0.5 & 1.5 & 0.5 & 1 & 1.5 \\
0.5 & 2 & 0.5 & 1 & 2.5 \\
0.5 & 2.5 & 0.5 & 1 & 0.5 \\
0.5 & 3 & 0.5 & 1 & 0 \\
\hline
\end{tabular}

Note: Composition of the samples collected from river, polluted by atrazine and fortified' with dechlorinated atrazine $\left[0.75 \mu \mathrm{g} \cdot \mathrm{mL}^{-1}\right]$.

\section{Results and Discussion}

\subsection{Mechanism of the Dechlorination of Atrazine}

Most halogenated hydrocarbons, RX, can be reduced by iron metal. The overall reaction (Equations A, B and C) results in dehalogenation of RX. Three general pathways by which this process may occur have been proposed (Matheson \& Tratnyek, 1994). The first involves direct reaction of the metal surface, in which case equation (A) 
alone adequately represents the pathway of reduction. The other two possible pathways do not involve the metal surface directly. Instead, $\mathrm{Fe}^{2+}$ and $\mathrm{H}_{2}$, which are products of corrosion by water, serve as the reductants that are directly responsible for dehalogenation of $\mathrm{RX}$ equation $\mathrm{B}$ and $\mathrm{C}$.

$$
\begin{array}{ll}
\mathrm{Fe}^{0}+\mathrm{RX}+\mathrm{H}^{+} \leftrightarrow \mathrm{Fe}^{2+}+\mathrm{RH}+\mathrm{X}^{-} & \mathrm{A} \\
2 \mathrm{Fe}^{2+}+\mathrm{RX}+\mathrm{H}^{+} \leftrightarrow 2 \mathrm{Fe}^{3+}+\mathrm{RH}+\mathrm{X}^{-} & \mathrm{B} \\
\mathrm{H}_{2}+\mathrm{RX} \leftrightarrow \mathrm{RH}+\mathrm{H}^{+}+\mathrm{X}^{-} & \mathrm{C}
\end{array}
$$

More specifically the atrazine can be written as $\mathrm{RX}(\mathrm{X}=\mathrm{Cl})$.

With zero valent iron powder in the acidic aqueous solution, the hydrogen can replace the chlorine, according to the following reaction:<smiles>CCNc1nc(Cl)nc(N(CC)NCC)n1</smiles>

\subsection{Effect of the Dechlorination of Atrazine on Its Extinction Coefficient Absorption}

UV absorption spectra of atrazine in aqueous solution $\left(1.5 \mu \mathrm{g} . \mathrm{mL}^{-1}\right)$ were recorded and compared to the spectra of the by-product obtained by the treatment of atrazine as shown in figure 1. Atrazine was dechlorination by zero valent iron powder according to the method described by Matheson et al. (1994).

The extinction coefficient of the atrazine at the $220 \mathrm{~nm}$ (maximum of absorption) was estimated the value of $35200 \mathrm{M}^{-1}$.L; whereas the extinction coefficient of the dechlorinated atrazine which gives a maximum at $210 \mathrm{~nm}$ was found equal to $169000 \mathrm{M}^{-1} . \mathrm{L}$ (Figure 1).

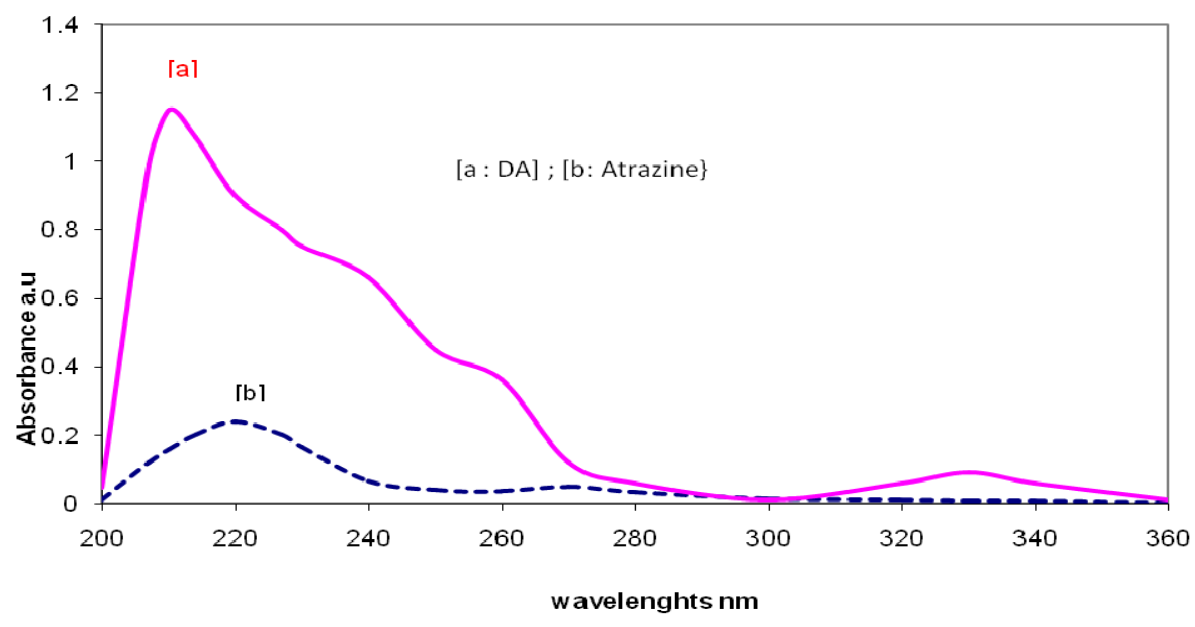

Figure 1. UV-Vis absorption spectra of [a]: dechlorinated atrazine [DA], by zero valent iron powder and [b] of atrazine

The experimental observations revealed that by the removal of the chlorine atoms hyperchromic and hypsochromic effects were observed. An increasing of the extinction coefficient and a blue shift from $220 \mathrm{~nm}$ to $210 \mathrm{~nm}$ of the maximum of absorption were detected.

According to the Table 4, the proton that accompanies the formation of the free amine in Equilibrium 1 is available to protonate other reactants in the solution (Equilibria 2 and 3). Addition of the free amine to a protonated molecule of formaldehyde leads to the formation of the iminium ion shown at the right of (Equilibria 4). The enol of ketone then adds to the carbon atom of the iminium ion in (Equilibrium 5). 
Table 4. The Mannich Mechanism (Francis \& Carey, 2007)

Equilibrium $1 \mathrm{H} \ddot{\mathrm{H}}\left(\mathrm{CH}_{3}\right)_{2}+\mathrm{H}^{\oplus} \rightleftharpoons \stackrel{\oplus}{\stackrel{\oplus}{\mathrm{N}}\left(\mathrm{CH}_{3}\right)_{2}}$

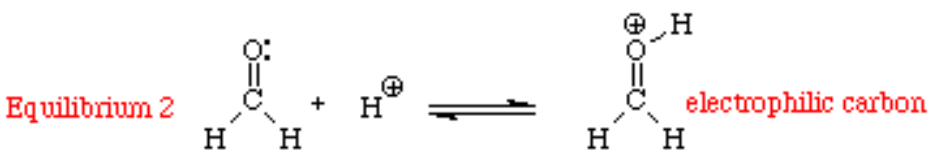

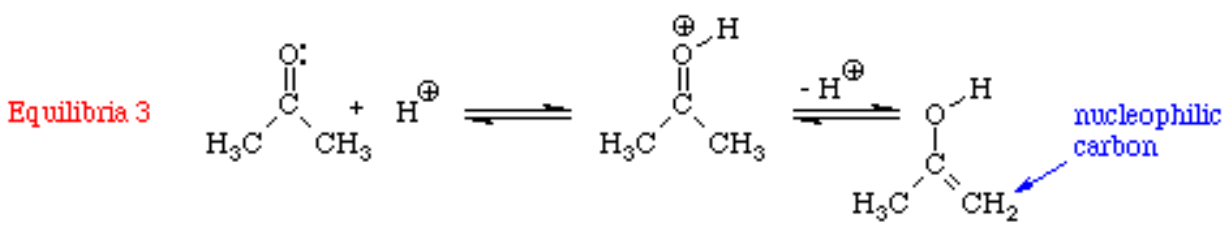

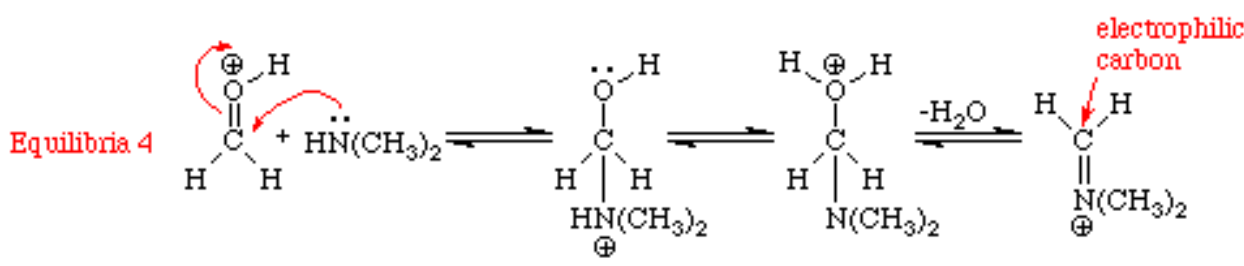

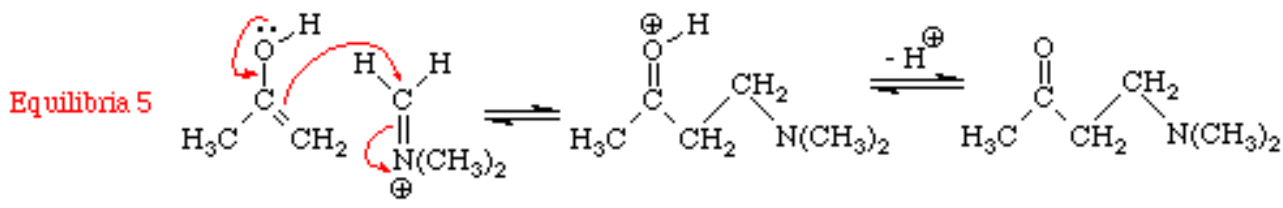

In the equilibrium 1 as shown in the Table 1 , the nitrogen is enriched by electrons of the $\mathrm{CH}_{3}$ group and this nitrogen will react with $\mathrm{H}+$ as base/acid reaction. However, when the electrons of the nitrogen, are deprived under the influence of the electron affinity of chlorine, this nitrogen will lose its basic character, then the équilibre 1 should be disturbed .In the other hand the nitrogen of the Equilibrium 4 play a nucleophilic role and, if this nitrogen is disadvantaged by a chlorine attractive effect; it will lose the nucleophilic characteristics and the reaction with the carbon of the aldehyde in the Equilibrium 4. Cannot be obtained.

After the removal of atrazine chlorin, the Mannich reaction was observed as we demonstrated experimentally.

\subsection{Identification of the Complex Obtained in the Mixture Atrazine Dechlorinated-formaldehyd and Uranine}

The Mannich reaction is an organic reaction which consists of an amino alkylation of an acidic proton placed next to a carbonyl functional group with formaldehyde and ammonia or any primary or secondary amine. The final product is a $\beta$-amino-carbonyl compound also known as a Mannich base. Reactions between aldimines and $\alpha$-methylene carbonyls are also considered Mannich reactions because these imines form between amines and aldehydes.
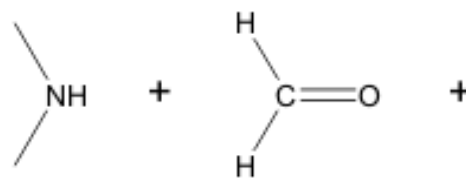<smiles>[R]C(=O)C(C)C</smiles><smiles>[R]C(=O)C(C)(C)CN(C)C</smiles>

Equation D

(Mannich \& Krosche, 1912) 
We hypothesized that the reaction between uranine, formaldehyde and dechlorinated atrazine must be similar to reaction $\mathrm{E}$. The expected mechanism is the following:<smiles>CCNc1ncnc(NC(C)C)n1</smiles>

Equation $\mathrm{E}$

Atrazine compound presents a UV spectrum with a maximum absorbance at $220 \mathrm{~nm}$ whereas dechlorinated atrazine presents a maximum of absorption at $210 \mathrm{~nm}$ Spectra of atrazine and dechlorinated atrazine are presented in Figure 1.

The mixture of dechlorinated atrazine, formaldehyde and uranine give rise to the formation of a complex described by the Mannich reaction. It is obvious that formaldehyde does not have any UV spectrum. The UV spectra of the complex give rise to a spectrum with two maxima at $207 \mathrm{~nm}$ and $227 \mathrm{~nm}$ respectively. Figure 2 presents the spectra of atrazine, dechlorinted atrazine and the complex obtained by Mannich reaction.

Figure 3 illustrates the change of the absorption spectra of the complex at two different concentrations of atrazine $\left(0.45 \mu \mathrm{g} \cdot \mathrm{mL}^{-1}\right.$ and $\left.0.90 \mu \mathrm{g} \cdot \mathrm{mL}^{-1}\right)$ while the formaldehyde and uranine are kept at constant concentrations.

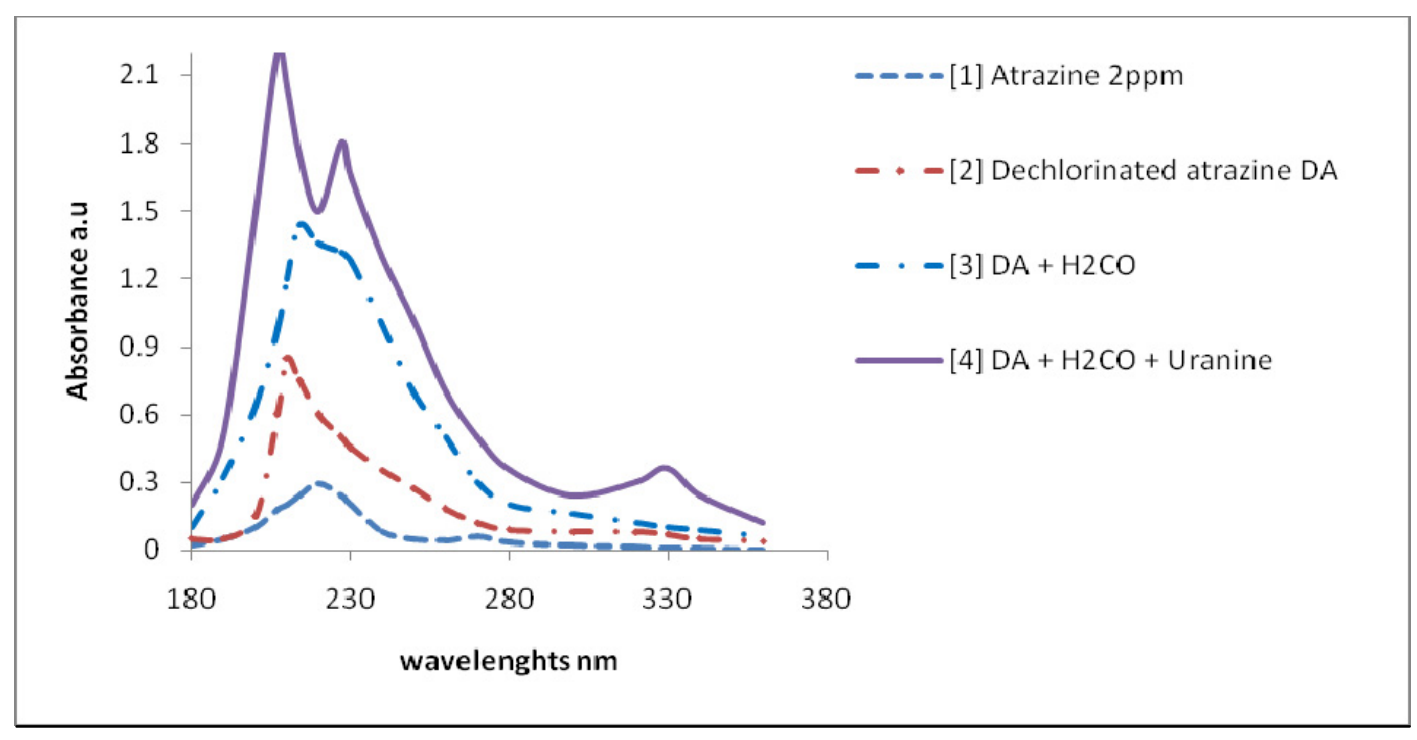

Figure 2. UV-Vis absorption spectra of the following solutions

- $\quad$ Atrazine $2 \mu \mathrm{g} \cdot \mathrm{ml}^{-1}$ (A)

- (DA : dechlorinated atrazine by zero valent iron powder),

- ( DA $+\mathrm{H}_{2} \mathrm{CO}$ : dechlorinated atrazine by zero valent iron powder with formaldehyde)

- (DA $+\mathrm{H}_{2} \mathrm{CO}+$ uranine: dechlorinated atrazine by zero valent iron powder with formaldehyde) 


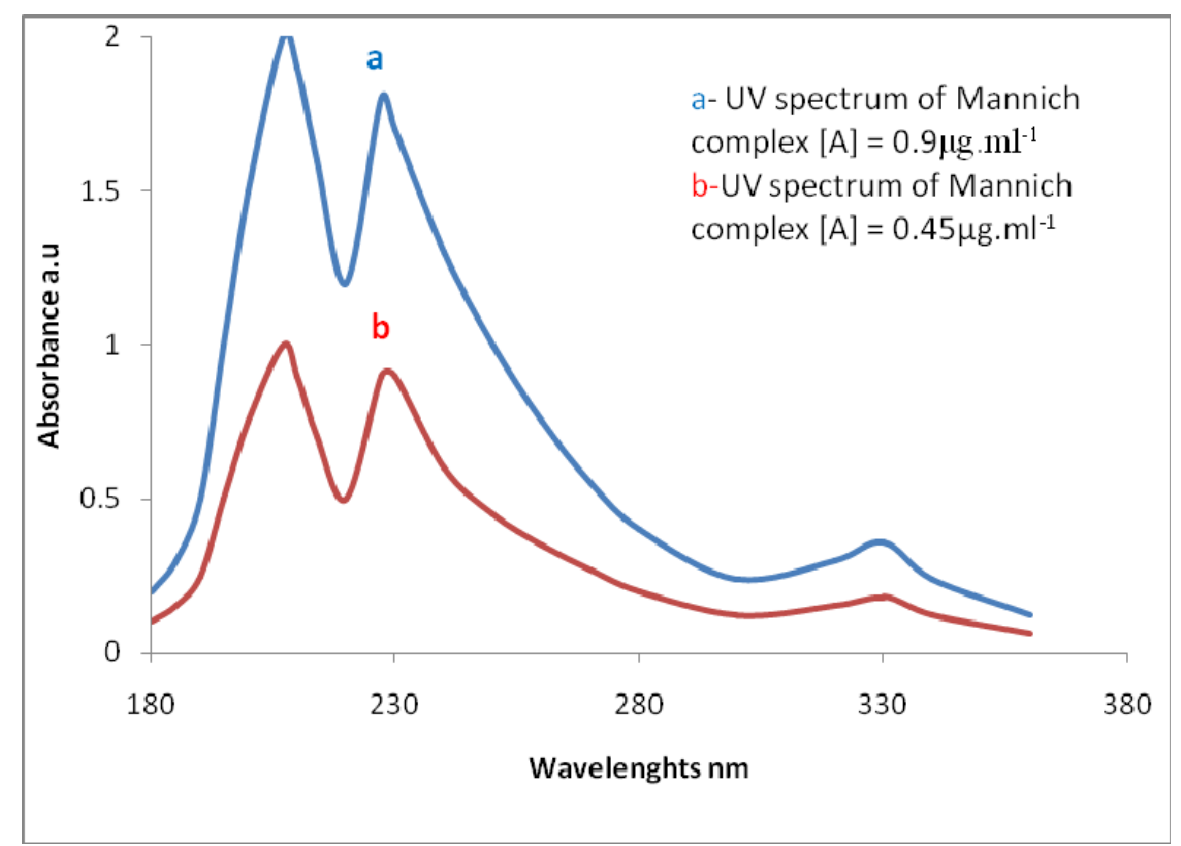

Figure 3. UV-Vis spectra of the complex obtained after treatment of atrazine by Mannich reaction. The concentration of atrazine are respectively $0.45 \mu \mathrm{g} / \mathrm{ml}$ and $0.9 \mu \mathrm{g} / \mathrm{ml}$

\subsection{Regression Curve between the Complex Formations}

A calibration curve of the complex was built to examine the linearity of the complex absorbance and atrazine concentrations. The least square method was used to calculate the regression equation. A strong linear correlation was obtained between the absorbance of the complex and the concentrations of atrazine. Figure 4 shows the regression curve of complex absorbance in function of atrazine concentrations. Correlation coefficients were higher than 0.99 in a concentration range of $0.15 \mu \mathrm{g} \cdot \mathrm{mL}^{-1}$ to $0.75 \mu \mathrm{g} \cdot \mathrm{mL}^{-1}$. The precision of the method was evaluated with relative standard deviations (RSD) of atrazine determination in five samples. RSD was $3 \%$. The limit of detection of the method was $0.01 \mu \mathrm{g} . \mathrm{mL}^{-1}$ as defined by a signal-to-noise ration of 3:1 (MacDougall \& Crummett, 1980).

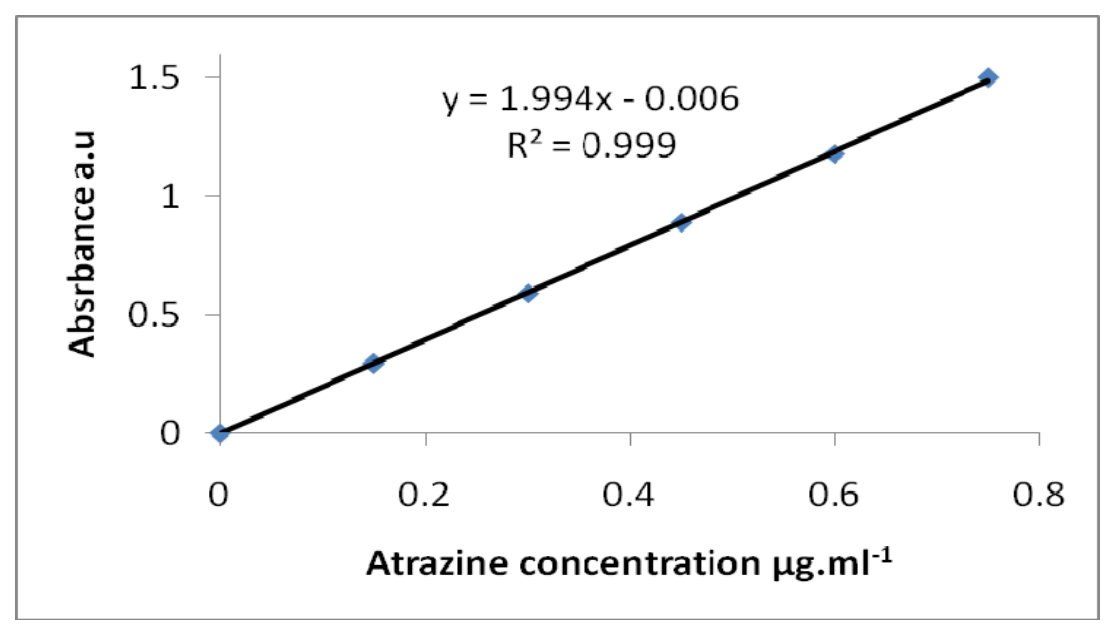

Figure 4. Regression curve of complex absorbance in function of atrazine concentrations 


\subsection{Spectrophotometric Method for Quantification of Atrazine Using the Internal Standard Addition Model}

A spectrophotometric method using the internal standard addition was examined to quantitatively determine atrazine concentrations in samples. A calibration curve was described by the following equation: $\mathrm{A}^{*}=\mathrm{aC}+\mathrm{b}$, which is equivalent to $A^{*}=\left(\mathrm{A}_{0}^{*} / \mathrm{C}_{0}\right) \times \mathrm{C}_{\mathrm{add}}+\mathrm{A}_{0}{ }^{*}$, with $\mathrm{A}^{*}=\left(\mathrm{A} / \mathrm{A}_{0}\right)$ normalized absorbance intensity (arbitrary values), is equal to the ratio of the absorbance intensity after adding the internal standard $A$ to the absorbance intensity before adding the internal standard $\left(\mathrm{A}_{0}\right)$

$\mathrm{C}_{0}$ : solute concentration to be estimated. $\mathrm{C}_{0}$ is determined by the negative intercept of the curve with the abscissa axis (Muel \& Lacroix, 1960; Rima, Lamotte \& Joussot-Dubien, 1982).

$\mathrm{A}_{0} *$ : normalized absorbance intensity into arbitrary units of the starting solution

$\mathrm{C}_{\text {add: }}$ : known added concentrations.

The plot of $\mathrm{A}^{*} v s . \mathrm{C}_{\mathrm{add}}$ is shown in Figure 5.

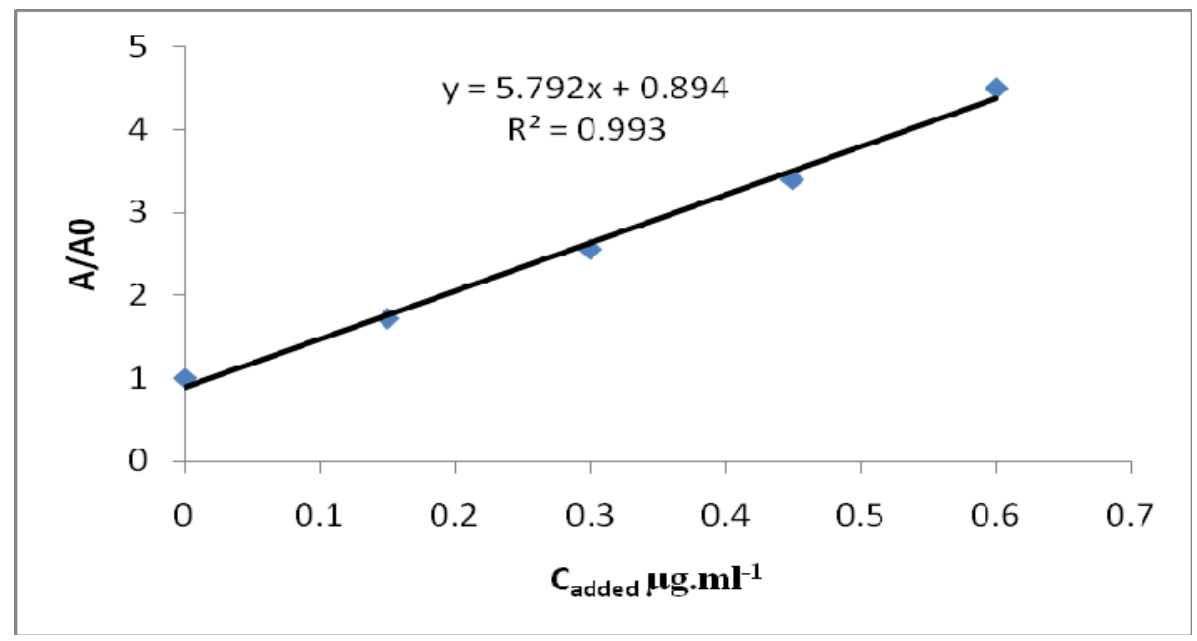

Figure 5. Plot of $\mathrm{A} / \mathrm{A} 0$ vs $\mathrm{C}_{\text {add }}$. Internal standard curve

The internal standard used in this method was the atrazine that we would like to determine $\left(\mathrm{C}_{0}\right)$. To this initial solution, different known concentrations $\left(\mathrm{C}_{\text {add }}\right)$ were added.

The average recovery for five samples spiked with atrazine as described above in Table 1 was estimated to be $97 \% \pm 3$. Table 5 summarizes the validation parameters of this method.

Table 5. Validation parameters of the internal standard addition method for the quantitative analysis of atrazine by Mannich reaction

\begin{tabular}{lc}
\hline Method & Spectrophotometer \\
\hline Standard linearity & -0.155 \\
Intercept & 5.792 \\
Slope & 0.99 \\
$\mathrm{R}^{2}$ & $0.15-0.75$ \\
Range $(\mu \mathrm{g} / \mathrm{mL})$ & 0.155 \\
Mean $(\mu \mathrm{g} / \mathrm{mL})$ & 3 \\
Precision $(\mathrm{n}=5)(\mathrm{RSD})(\%)$ & $97.0 \pm 3$ \\
Mean recovery $(\%) \pm$ standard deviation & 0.01 \\
Detection limit $(\mu \mathrm{g} / \mathrm{mL})$ & \\
\hline
\end{tabular}




\subsection{Spectrophotometric Quantitative Measurement of Atrazine, in Natural Samples, Using Internal Standard Method}

Samples from contaminated water with atrazine were processed by zero valent iron powder for the dechlorination of atrazine molecules. A definite volume of this solution is mixed with the same concentrations of formaldehyde and uranine. Different volumes of standard solution of dechlorinated atrazine were added to the solutions to be analyzed. The composition of these solutions is summarized in Table 3 .

The UV-Vis spectra of the solutions were recorded to follow the evolution of the complex obtained after the mixture called Mannich mixture.

The atrazine in natural samples was determined by a simple spectrophotometric method using Mannich reaction and the internal standard addition method. The estimated concentration found in the river water was $0.29 \pm 0.011$ $\mu \mathrm{g} \cdot \mathrm{mL}^{-1}(n=5)$.

\section{Conclusion}

The spectrophotometric method used to analyze the atrazine in agriculture water was based on Mannich reaction. This new method is a specific and simple method for the quantitative determination of atrazine in the contaminated water. Often the determination of atrazine is measured by sophisticated and expensive methods like HPLC, GC/MS. However the proposed method is easy to use, rapid and economic and it showed high accuracy, but it was restricted by the sensitivity of the spectrophotometer which reaches a limit of detection of $0.01 \mu \mathrm{g} \cdot \mathrm{mL}^{-1}$ as described in the manuscript.

\section{References}

Baranowska, I., Barchanska, H., \& Pacak, E. (2006). Determination of triazines herbicides by HPLC and metals by TCP-AES methods. Environ. Pollut., 143, 206-211.

EEC Drinking Water Guidelines. (1980a). 80/778/EEC, EEC No. L229/11-29; EEC: Brussels, Aug 30, 1980.

EEC Drinking Water Guidelines. (1980b). 80/779/EEC, EEC No. L229/11-29; EEC: Brussels, Aug 30, 1980.

Francis, A., \& Carey, A. (2007). Advanced Organic Chemistry, Part A: Structure and Mechanisms. Sundberg (Jun 13, 2007).

Gammon, D. W., Aldous, C. N., Carr, W. C. Jr., Sanborn, J. R., \& Pfeifer, K. F. (2005). A risk assessment of atrazine use in California: human health and ecological aspects. Pest Manag Sci., 61, 331-355.

Ghauch, A., Rima, J., Amine, C., \& Martin-Bouyer, M. (1999). Rapid treatment of water contamined with atrazine and parathion with zero-valent iron. Chemosphere, 39, 1309-1315.

Gianessi, L. P., \& Marcelli, M. B. (2000). Pesticide use in U.S. crop production 1997: "National Summary Report" National Center for Food and Agricultural Policy.

Grennan, K., Strachan, G., Porter, A. J., Killard, A. J., \& Smyth, M. R. (2003). Atrazine analysis using an amperometric immunosensor based on single-chain antibody fragments and regeneration-free multi-calibrant measurment. Anal. Chim. Acta, 500, 287-298.

Jiang, H., Adams, C., Graziano, N., Roberson, A., McGuire, M., \& Khiari, D. (2006). Occurance and removal of chloro-s-triazines in water treatment plants. Environ. Sci. Technol., 40, 3609-3616.

Koal, T., Asperger, A., Efer, J., \& Engewald, W. (2003). Simultaneous determination of a wide spectrum of pesticides in water by means of fast on-line SPE-HPLC-MS-MS - a novel approach. Chromatographia, 57, 93-101.

MacDougall, D., \& Crummett, W. B. (1980). Guidelines for data acquisition and data quality evaluation in environmental chemistry. Anal. Chem., 52, 2242-2249.

Maleki, N., Absalan, G., Safavi, A., \& Farjami, E. (2007). Ultra trace adsorptive stripping voltammetric determination of atrazine in soil and water using mercury film electrode. Anal. Chim. Acta, 581, 37-41.

Mannich, C., \& Krosche, W. (1912). Reaction of compounds having an active hydrogen with non-enolizable aldehydes. Arch. Pharm., 250, 647-667.

Matheson, L. J., \& Tratnyek, P. G. (1994). Reductive dehalogenation of chlorinated methanes by iron metal. Environ. Sci. Technol., 28, 2045-2053.

Muel, B., \& Lacroix, G. (1960). Analyses des hydrocarbures aromatiques polynucléaires dans l'air. Bulletin de la société chimique de France, 11-12, 2139-2147. 
Nevado, J. J. B., Cabanillas, C. G., Llerena, M. J. V., \& Robledo, V. R. (2007). SPE GCMS-SIM screening of endocrine-disrupting herbicides and related degradation products in natural surface waters and robustness study. Microchem. J., 87, 62-71.

Rima, J., Lamotte, M., \& Joussot-Dubien, J. (1982). Application of the shpolskii effect to quantitative analysis of monomethylphenanthrene isomers. Analytical Chemistry, 54, 1059-1070.

Stalikas C., Knopp, D., \& Niessner R. (2002). Sol-Gel Glass Immunosorbent-Based Determination of s-Triazines in Water and Soil Samples Using Gas Chromatography with Nitrogen Phosphorous Detection System. Environ. Sci. Technol., 36, 3372-3377.

Turiel, E., Fernandez, P., Perez-Conde, C., Gutierrez, A. M., \& Camara, C. (1998). Flow-through fluorescence immunosensor for atrazine determination. Talanta, 47, 1255-1261.

Usenko, S., Hageman, K. J., Schmedding, D. W., Wilson, G. R., \& Simonich, S. L. (2005) Trace analysis of semivolatile organic compounds in large volume samples of snow, Lake. Water, and Groundwater. Environ. Sci. Technol., 39, 6006-6015. 